\title{
CENSORSHIP ON DIGITAL PLATFORMS AND SOCIAL MEDIA VERSUS FREEDOM OF EXPRESSION AND PLURALISM: THE PERSPECTIVE OF THE REPUBLIC OF POLAND
}

\author{
BARTŁOMIEJ ORĘZIAK
}

\section{Introduction}

It is a truism to say that the world is constantly changing, and the $21^{\text {st }}$ century perhaps best exemplifies this. The process of civilization, concomitant with technological and technical progress, that we are witnessing is an expression of people's desire to simplify and expand performance and efficiency in whatever they do. This is true for the vast majority of the areas of human life, from advanced financial transactions through new ways of learning to everyday shopping or playing chess. Law-as a multifaceted plane of legal norms defining individuals' rights, freedoms, and obligations, and thus linked with most areas of human life-is no exception. This means that the legal doctrine is also involved in the debate on the practical application of advanced technologies, in terms, for example, of their potential, the definition of the rules of legal liability, and the choice of law and jurisdiction in crossborder cases. This discussion is both theoretical and practical. Legal theory deals with the conceptualization or creation of new legal frameworks or the adaptation of traditional ones that define legal norms for new technologies. On the other hand, the practice of law focuses on implementing aspects of new technologies in terms of

Bartłomiej Oręziak (2021) Censorship on Digital Platforms and Social Media Versus Freedom of Expression and Pluralism: the Perspective of the Republic of Poland. In: Marcin Wielec (ed.) The Impact of Digital Platforms and Social Media on the Freedom of Expression and Pluralism, pp. 47-78. BudapestMiskolc, Ferenc Mádl Institute of Comparative Law-Central European Academic Publishing. 
their actual operation and validating legal norms devised in the theory of law. Major examples of such legal considerations, if only due to the current pandemic caused by the novel coronavirus (Covid-19) virus, are digital medicine, ${ }^{1}$ e-health, ${ }^{2}$ m-health, ${ }^{3}$ telehealth, ${ }^{4}$ telemedicine, ${ }^{5}$ telecare,${ }^{6}$ sensory health, ${ }^{7}$ and medical informatics. ${ }^{8}$

The scholarly issue presented for analysis is of great importance, not only to the theory of law, but also for its practical value. This is because, on the one hand, the discussion about censorship on digital platforms and social media in the context of freedom of expression and pluralism from the perspective of the Republic of Poland may bring a new contribution to legal science in a dogmatic sense. On the other hand, however, this analysis will answer the fundamental question about the restriction, or even destruction, of the essence of freedom of expression and pluralism on the Internet. The real activities of the entities that control websites are on the table, as these directly affect ordinary Internet users. This undoubtedly shapes the perception of what an individual is allowed or forbidden to do, punished for, and what rights they have. This influence is even more palpable if one considers that in 2020, as many as $89 \%$ of the European Union (EU) population declared that they used the Internet, ${ }^{9}$ which is today referred to as a globally important area of activity. ${ }^{10}$ The popularity of the Internet as such is constantly growing, providing a platform for traditional human activity to be performed in an innovative way. This not only has positive but also negative consequences, as it results in the emergence of dangers, in the form, for example, of cybercrime, entailing criminal liability on the Internet.

In dictionary terms, censorship means "official examination, usually under governmental control, of prints, press, literary works and motion pictures, etc., exercised by a specially appointed authority that evaluates them in political or moral terms"11 or "official control of publications, theatrical performances, radio programs, etc., [and the] evaluation [of] these in political or moral terms." ${ }^{12}$ These definitions are, of course, correct. However, they mainly result from the negative historical connotations of censorship in Poland. These date back to 1949-1989 when Poland was under communist rule based on the censorship of public life and specifically under the Decree of 5 July 1946, which established the Main Office for the Control of the

1 Lupton, 2013, p. 257; Elenko, Underwood, and Zohar, 2015, pp. 456-461; André, 2019, p. 4.

2 Terry, 2000, pp. 605-607; Mars and Scott, 2010, pp. 237-243; de Pietro and Francetic, 2018, pp. 69-74.

3 Paglialonga et al., 2019, p. 6; Istepanian, Laxminarayan, and Pattichis, 2006, p. xxiii; Sezgin, 2018, p. 1.

4 Maimone et al., 2012, pp. 791-793; Wang et al., 2014, pp. 314-324.

5 Klar and Pelikan, 2011, p. 1119; Linkous, 2001, p. 226.

6 Držanič et al., 2019, p. 252; Afsarmanesh, Masís, and Hertzberger, 2004, pp. 211-212.

7 Gao et al., 2020, pp. 55-56.

8 Huang, 2009, p. 1423.

9 Eurostat (25 May 2021), https://ec.europa.eu/eurostat/databrowser/view/isoc_ci_ifp_iu/default/ table?lang $=$ en .

10 Dutton, 2013, p. 1.

11 Doroszewski [Online], https://sjp.pwn.pl/doroszewski/cenzura;5416093.html.

12 Słownik Języka Polskiego [Online], https://sjp.pwn.pl/sjp/cenzura;2447537.html. 
Press, Publications, and Public Performances. ${ }^{13}$ The decree introduced political and preventive censorship in almost every aspect of life. In today's world, however, the concept of censorship may have a slightly different meaning. It does not always mean official or state-run control, especially as far as digital platforms and social media are concerned. This digitized environment should ex definitione warrant a tailored meaning of censorship that is more colored with digital elements. It seems that in this case, censorship can be understood in the paradigm presented above, yet with the necessary changes. In view of this, for the purposes of this chapter, censorship will mean the control and restriction of Internet users' activities, including their publication of content, in particular on political, moral, or legal grounds. This is a key point, as in the operating practice of digital platforms and social media, it may turn out that a legal norm will not form the basis for determining the extent of rights, freedoms, and penalties..$^{14}$ It would then be nothing more than unlawful censorship, that is, a measure without a basis in the generally applicable law in Poland. On the other hand, it might well be that in a formal sense, the source of restrictions on human rights and freedoms on the Internet is in the law. In this case, the term 'lawful censorship' should be used. The latter, however, does not mean that it is reasonable or justified, but that it is based on statutory law in Poland. ${ }^{15}$

It therefore seems appropriate to analyze the three main research areas related to the issue delimited in the title. First, we will discuss the lawful censorship of content posted on the Internet using the example of copyright law, the original legal basis of which is found in the EU regulations within the meaning in line with the Court of Justice of the European Union's (CJEU) latest case law. Without jumping to conclusions on this point, one may safely indicate that the matter is about weighing certain legally protected interests. On the one hand, these are human rights, i.e., freedom of expression and pluralism, and on the other, the copyright holder's equitable claims. Second, no less important is an analysis of the issues of unlawful censorship on digital platforms and social media in Poland, based on the Polish legislator's latest legislative effort. Third, the first and the second areas above should provide a basis for the assessment of the consistency of lawful and unlawful censorship with the standard of freedom of expression and pluralism, as understood in accordance with the Polish system of human rights protection.

13 Decree of 5 July 1946 establishing the Main Office for the Control of the Press, Publications, and Public Performances (Journal of Laws of 1946, No. 34, item 210). Declared repealed on the basis of the Press Law Act of 26 January 1984 (consolidated text: Journal of Laws of 2018, item 1914).

14 For instance, in the cases of the numerous website rules that have been issued and are currently in operation.

15 Legal acts enacted in Poland enjoy the presumption of constitutionality until rebuttal. This means that law made, passed, and applied in the Polish legal system (in the form of an act/statute, as discussed below), including a law restricting selected human rights and freedoms, is treated as constitutional until the Polish Constitutional Court declares it inconsistent with the Constitution. In this context, see Radziewicz, 2008, pp. 55-86; and the following judgements of the Constitutional Court: 18 March 2004, case ref. P21/02; 25 May 2016, case ref. Kp 2/15; 5 May 2011, case ref. P 110/08; July 2012, case ref. K 8/10. 


\section{Lawful censorship in Poland in light of EU copyright}

Poland, as an EU member state, is required to apply and abide by EU law and comply with the CJEU's rulings. This is an indisputable fact resulting from Poland's commitments and obligations under international agreements and treaties. ${ }^{16}$ Another undeniable fact is that for EU law to be construed properly, CJEU rulings, which, through the court's autonomous interpretation either creates or clarifies legal norms adopted by the EU legislator, are of key importance. ${ }^{17}$ It should be noted that the EU case law system, unlike the Polish legal system, is based on precedent and thus has a law-making character. ${ }^{18}$ This often leads to peculiar situations, where a single provision, or even part of it, serves to build an autonomous line of case law that fundamentally changes the existing legal position on a subject. In practice, these changes may be so far reaching that questions emerge about their compatibility with the EU legislator's original intent, which represents the EU member states' intent. Due to the law-making nature of CJEU case law as emphasized above, and the obligation on the part of EU member states to apply EU law in line with the CJEU's autonomous interpretation, ${ }^{19}$ this issue is of great significance for legal transactions.

Directive 2001/29/EC of the European Parliament and of the Council of 22 May 2001 on the harmonization of certain aspects of copyright and related rights in information society ${ }^{20}$ (Directive 2001/29/EC), based on today's Articles 53, 62, and 114 of the Treaty on the Functioning of the European Union (TFEU), ${ }^{21}$ concerns the legal protection of copyright and related rights within the EU internal market, with particular emphasis on information society. Pursuant to Recital 1 of Directive 2001/29/ EC, its purpose is to contribute to the achievement of the objectives of the EU internal market, including the institution of a system ensuring undistorted competition. ${ }^{22}$

The issue of Internet censorship is related to the admissibility of content publication on the Internet in accordance with EU copyright law under Directive 2001/29/ EC. In this respect, proper interpretation of Article 3(1) of Directive 2001/29/EC is key. It states that:

Member States shall provide authors with the exclusive right to authorize or prohibit any communication to the public of their works, by wire or wireless means, including the making available to the public of their works in such a way that members of the public may access them from a place and at a time individually chosen by them.

16 Treaty of Accession between the Kingdom of Belgium ... the Slovak Republic, concerning the accession of the Czech Republic ... the Slovak Republic to the European Union, signed in Athens on 16 April 2003, OJ L 236, 23.9.2003 (Journal of Laws of 2004, No. 90, item 864).

17 Helios and Jedlecka, 2018, pp. 134-141.

18 Zawidzka-Łojek and Grzeszczak, 2015, pp. 3-5.

19 Helios and Jedlecka, 2018, pp. 134-141.

20 OJ L 167, 22.6.2001, p. 10.

21 OJ C 326, 26.10.2012, p. 1.

22 Rosenmeier, Szkalej, and Wolk, 2019, p. 216. 
As it has turned out in the practice of the application of Directive 2001/29/EC, the concept requiring the use of advanced interpretation techniques has been (and still is) 'communication available to the public,' as used in Article 3(1) of that directive. It seems that at least two scholarly problems are inescapable with this point. First, does the inclusion of a hyperlink to a protected work that is freely accessible on another website without the copyright holder's permission constitute 'communication to the public' within the meaning of that provision? The facts associated with this problem carry, in principle, a negative load. An example may be a case where computer software, which is freely available on a website, is made available on another website without the developer's license. Another typical example would be downloading videos or songs and sharing these instantaneously without their creators' consent. Second, does the inclusion of a hyperlink to a protected work that is freely accessible on another website with the copyright holder's permission constitute 'communication to the public' within the meaning of the same provision? The facts associated with this problem do not, in principle, carry a negative load. An instance of this may be downloading a photo that is freely available on a website with the photographer's consent and then making it available on another website, with attribution of the photo's source. Another typical example is the use of the 'share' function that most digital platforms and social media offer.

As is clear, the difference between the first and the second problem is whether or not the copyright holder has given their consent. This is of key importance from the interpretation point of view, because, as it will turn out, this factor is a root cause of the CJEU's adoption of a different autonomous interpretation. The reconstruction of the legal model for the admissibility of hyperlinking on the Internet from Poland's perspective as an EU member state will only follow once the proper understanding of the law with respect to these two issues has been established. The CJEU's case law, which brings a novel normative solution to the Polish legal system, is gaining importance.

Poland has transposed a number of legal measures that have implemented not only Article 3(1) of Directive 2001/29/EC but generally all the legal norms contained in this directive. ${ }^{23}$ The transposition was made under the Copyright and Related Rights Act of 4 February 1994. ${ }^{24}$ However, Polish implementation was based on the literal construction of these provisions, established as at 22 May 2001, in fulfilment of the obligation under Article 13 of Directive 2001/29/EC. ${ }^{25}$ This means that

23 Act of 1 April 2004 amending the Copyright and Related Rights Act (Journal of Laws of 2004, No. 91, item 869).

24 Copyright and Related Rights Act of 4 February 1994 (consolidated text: Journal of Laws of 2020, item 288).

25 Pursuant to Article 13 of Directive 2001/29/EC, EU member states were obliged to bring into force the laws, regulations, and administrative provisions necessary to comply with the directive at the latest by 22 December 2002. Poland, however, joined as an EU Member State on 1 May 2004 pursuant to the Accession Treaty. Therefore, Directive 2001/29/EC was transposed into the Polish normative system, justifiably, at a later date. 
Poland has demonstrated the best faith in the objectives of that act of EU law and, in general, in the EU legislation imposing obligations on it. One must not forget that the literal construction of Directive 2001/29/EC can and should be deemed equivalent to the EU member states' intent, as represented by the European Parliament and other EU institutions. No other conclusion may be made than that the standards of the EU copyright law agreed by the EU member states have the wording established as at 22 May 2001 and the form of an EU directive. An EU regulation was not issued back then, and rightly so, probably to avoid the direct effect of EU law within national legal systems. EU member states wanted to remain autonomous as to the measures implementing the normatively defined objective of Directive 2001/29/EC. However, in the context of its Article 3(1), it seemed, at that moment, sufficient to transpose the legal norm and understand it in accordance with the literal rule of interpretation, where the concept of communication to the public has its common and ordinary meaning. That was the case until the GS Media ruling. ${ }^{26}$ At that moment, the CJEU obtruded with its powers of autonomous construction. In its rulings in the cases of GS Media, FilmSpeler, ${ }^{27}$ The Pirate Bay, ${ }^{28}$ and Renckhoff, ${ }^{29}$ the CJEU gave autonomous interpretations of Article 3(1) of Directive 2001/29/EC that drastically changed the understanding of the concept of communication to the public, based on the argument that the concept has a specific meaning in EU law.

In view of the binding nature of the CJEU's autonomous interpretation, ${ }^{30}$ this is tantamount to the introduction into the legal system of a specific type of construction norm that determines the actual content of Article 3(1) of Directive 2001/29/EC. It radically changes the rules of the admissibility of hyperlinking on the Internet from the copyright perspective, a matter that has thus far been understood otherwise. As a result, Poland was obliged to construe its legal measures implementing Directive 2001/29/EC through the prism of the CJEU's autonomous interpretation in the context of its Article 3(1). This is a very interesting legal problem. One may conclude that to issue an EU directive does not clearly mean to avoid the risk of the unification of legal norms under a fixed EU standard. Such a risk may be realized against the intent of an EU member state which, through its representatives in the European Parliament, has agreed to adopt a legal act with the rank of a directive. It is sufficient for the CJEU to issue an autonomous interpretation that is directly applicable and gives rise to an EU member state's obligation to construe its legal system specifically

26 Judgement of the Court of Justice of the European Union of 8 September 2016 in case C-160/15 GS Media BV v Sanoma Media Netherlands BV, Playboy Enterprises International Inc., Britt Geertruida Dekker (ECLI:EU:C:2016:644).

27 Judgement of the Court of Justice of the European Union of 26 April 2017 in case C-527/15 Stichting Brein v Jack Frederik Wullems, also trading under the name 'Filmspeler' (ECLI:EU:C:2017:300).

28 Judgement of the Court of Justice of the European Union of 14 June 2017 in case C-610/15 Stichting Brein v Ziggo BV and XS4ALL Internet BV (ECLI:EU:C: 2017:456).

29 Judgement of the Court of Justice of the European Union of 7 August 2018 in case C-161/17 Land Nordrhein-Westfalen v Dirk Renckhoff (ECLI:EU:C:2018:634).

30 Helios and Jedlecka, 2018, pp. 134-141. 
in accordance with the proposed standard. It seems reasonable to conclude that the CJEU's case law may lead to the alteration of the normatively envisaged objectives of an EU directive. This is because the CJEU's autonomous interpretation imperatively and directly unifies the understanding of a directive's legal norms and thus indirectly influences the application of all legal measures taken to bring it into force in the national legal system. This is precisely the case with Article 3(1) of Directive 2001/29/EC. The conclusion is, therefore, that the autonomous interpretation the CJEU issued actually made it a legal norm of an EU regulation. In simplified terms, it turns out that the CJEU has the powers to change the legal nature of an EU legal norm from indirectly to directly applicable.

Therefore, Directive 2001/29/EC could be of significance for the Polish legal system in at least two dimensions. The first one would be typical and consistent with the essence of a legal act of this rank. The other one, in turn, would be burdened with the CJEU's autonomous interpretation. This could be because in the CJEU's ruling in the Svensson case, it decided that harmonization under Directive 2001/29/ EC is exhaustive and is achieved when various national laws governing an issue are replaced by a single EU standard. ${ }^{31}$ Therefore, from the Polish perspective, it makes no difference that Directive 2001/29/EC was passed as an EU directive and not an EU regulation. The CJEU could do so from the legal point of view, and it did. In simplified terms, it changed the legal rank of Directive 2001/29/EC, of course in observance of the transposition procedure into national law and therefore national autonomy as to the choice of measures to achieve the objectives, but without options to shape the interpretations. Whether the reader agrees with the above view or not, it is an undeniable fact that, in accordance with EU primary law, Poland is obliged under international law to construe its national law in line with the CJEU's autonomous interpretation of Article 3(1) of Directive 2001/29/EC.

From the point of view of the construction of Article 3(1) of Directive 2001/29/ EC as regards restrictions on posting content on the Internet due to copyright, the key is the autonomous interpretation made in the ruling in the GS Media case, where, for the first time, the CJEU introduced clear limits on the admissibility of hyperlinking on the Internet. The CJEU decided that Article 3(1) of Directive 2001/29/EC should be construed so that in order to establish whether placement on a website of hyperlinks to protected works that are freely accessible on another website without the copyright holder's permission constitutes 'communication to the public' within the meaning of that provision requires a determination as to whether such hyperlinks were made available for non-commercial purposes by a person who did not know or could not reasonably know about the unlawful nature of the publication of these works on that other website or whether, on the contrary, such hyperlinks were made available for commercial purposes, in which case such knowledge is to be presumed. ${ }^{32}$ The CJEU has consistently upheld that position in subsequent cases. First, 
it issued a ruling in the Filmspeler case where, based on the rules and constituent elements set out in GS Media case, it construed the third-party liability of a dealer selling a media player with pre-installed plug-ins (otherwise available on the Internet) containing hyperlinks to freely accessible websites featuring copyrighted works that had been placed there without the copyright holders' permission (hyperlinking in physical facilities). ${ }^{33}$ Second, it issued a ruling in The Pirate Bay case in which it made an extensive interpretation of the rules and constituent elements from the GS Media case and proposed a new principal accessory approach to hyperlinking. In that case, the CJEU decided that an Internet user justifiably incurs third-party liability in the construction of indirect communication (sharing) or aiding and abetting hyperlinking based on the sine qua non condition whereby if some users did not grant access to their website and did not manage it, other users would not be able to enjoy the protected work or would be able to do so only with difficulty. ${ }^{34}$ Third, it issued a ruling in the Renckhoff case that represents a different approach to the construction of Article 3(1) of Directive 2001/29/EC, though it does not entail a departure from the rules and constituent elements given in the GS Media case ruling, which remain intact. The ruling in the Renckhoff case is specific in that it concerns a situation where a hyperlink is placed to a protected work that is freely accessible on another website with the copyright holder's permission. Therefore, the adjudicating panel proposed that Article 3(1) of Directive 2001/29/EC in the context of hyperlinking to content that is legally available on the Internet should be examined only through the prism of a single element set out in in the GS Media case judgement, while withholding the other ones, including the commercial purpose of communication. That element is the concept of the public, as contrasted with the concept of a new public, from which, for example, it follows that the concept of communication to the public within the meaning of Article 3(1) of Directive 2001/29/EC should be construed so as to include the posting on a website of a photograph that has previously been published on another website without restrictions preventing its download and with the copyright holder's consent..$^{35}$ This is a new autonomous CJEU construction for the communication of content lawfully available on the Internet, i.e., with the copyright holder's consent. ${ }^{36}$

The abovementioned autonomous interpretations of Article 3(1) of Directive 2001/29/EC are only examples selected for the author's analysis. This means that there are currently more such constructions. ${ }^{37}$ Nevertheless, the abovementioned

33 Colangelo, Maggiolino, 2018, pp. 142-159; Ginsburg, 2017, pp. 4-5.

34 Visser, 2018, pp. 1025-1026; Koo, 2018, pp. 542-551; Nordemann, 2018, pp. 744-756.

35 Fernández-Díez, 2018, p. 2; Visser, 2018, pp. 183-190; Wang, 2018, pp. 61-65.

36 The considerations presented in this paragraph are contained in: Oręziak, 2017, pp. 243-253; Oręziak, 2018, pp. 199-219; Oręziak, 2018, pp. 137-157; Oręziak, 2019, pp. 181-192; Oręziak, 2019, pp. 432-448.

37 For example, the autonomous interpretation contained in: Judgement of the Court of Justice of the European Union of 9 March 2021 in case C-392/19 VG Bild-Kunst v Stiftung Preußischer Kulturbesitz (ECLI:EU:C:2021:181). 
autonomous interpretations are sufficient to present a picture of the system of the admissibility of posting content on the Internet under the EU copyright law that Poland is obliged to apply. The jurisprudence of common courts in Poland confirms that this obligation is being fulfilled, with examples including the Court of Appeal in Warsaw's 21 June 2016 decision, ${ }^{38}$ the Judgement of the District Court in Olsztyn on 6 June 2017, ${ }^{39}$ the Judgement of the Court of Appeal in Szczecin on 24 November $2016,{ }^{40}$ and the Judgement of the Supreme Court on 9 August $2019 .{ }^{41}$ These examples clearly demonstrate that Polish courts apply the CJEU's arguments and use them as the basis for decisions on legal liability for copyright infringement on the Internet. In this context, it should be emphasized that in Poland, as a rule, courts' jurisprudence does not enjoy law-making power, so court decisions are only binding on the parties to the proceedings and do not have an erga omnes nature. ${ }^{42}$ Nevertheless, other subjects tend to be inspired by such decisions, which they use as a basis for their rationale in claiming that their situation is identical or substantially identical to that which has been delimited by the facts of a decided court case. Therefore, on the one hand, Polish courts decide on the basis of the CJEU's constructions, and on the other, website administrators remove content on the basis of relevant jurisprudence in cases other than those decided within such jurisprudence. In such cases, the decision makers are not Polish courts but rather website administrators who, in their reliance on such premises, must be aware that their conduct possibly borders on unlawful censorship. Although one may say that such conduct is founded on generally applicable law in Poland, it should be noted that a website administrator is not an entity with powers to apply, enforce, and interpret the law in new cases that have not yet been examined in this regard by the competent bodies established for this purpose in Poland. Thus, even where such administrators observe the duty of utmost care, a court may still decide otherwise in a new case, on the grounds, for example, of the specific nature of the facts given in the case.

In conclusion, the example of censorship based on the EU copyright law in Poland as outlined above constitutes lawful censorship, where there is undoubtedly the exercise of control over and the restriction of Internet users' activities, including their publication of content, for legal reasons. It should be emphasized that lawful censorship only means that this type of censorship is sanctioned by generally applicable law in Poland. Assessment of this issue is rather difficult, as it is about a law that

38 Decision of the Court of Appeal in Warsaw of 21 June 2016, case ref. IA Cz 723/16.

39 Judgement of the District Court in Olsztyn of 6 June 2017, case ref. VII K 5/16.

40 Judgement of the Court of Appeal in Szczecin of 24 November 2016, case ref. I ACa 1159/15.

41 Judgement of the Supreme Court of 9 August 2019, case ref. II CSK 7/18.

42 This principle stems from Article 87 of the Constitution of the Republic of Poland, defining the sources of universally binding law in Poland. For example, a specific determination of this principle is the provision of Article 365 of the Polish Code of Civil Procedure (Code of Civil Procedure Act of 17 November 1964 (consolidated text Journal of Laws of 2021, item 11). Pursuant to this provision, a final decision is binding not only on the parties and the court that has passed it, but also on other courts and other state authorities and public administration bodies, and in the cases provided for in the Act and also on other persons. 
was lawfully passed in the EU and has been correctly implemented and brought into force in the Polish legal system then modified by an autonomous interpretation made by the CJEU. The pattern seems to be correct, as EU member states have agreed to it by deciding to join the EU or by ratifying the amendments to EU primary legislation, yet an interesting question is whether they were fully aware of the consequences. The brief analysis given above demonstrates that these consequences can be far reaching. In fact, it is not about the pattern itself, as it has its basis in international law, but rather about the content hidden in this pattern, and even more importantly, whether the content is consistent with freedom of expression and pluralism on the Internet, the standards of which are guaranteed in the Constitution of the Republic of Poland (Polish Constitution). ${ }^{43}$ It is a good point of reference because the act represents the supreme and unchallenged law in our country.

\section{Unlawful censorship in Poland and a new legislative initiative}

As noted above, unlawful censorship in Poland carries a negative load due to its roots in the communist rule. It should therefore come as no surprise that any form of censorship on digital platforms and social media is met with a negative response from the public. This is more intense where a basis for such restrictions is comprised not of a legal norm but other types of rules, for example, the terms of use of a specific social networking or other website. Of course, an Internet user will often accept such terms of use unmindfully, but this does not mean that censorship is then warranted to have a basis in generally applicable law in Poland. This is because, pursuant to Article 87 of the Polish Constitution, the sources of universally binding law in Poland are the Constitution, statutes, ratified international agreements and regulations, and enactments of local law issued by the operation of organs in the territory of the organ issuing such enactments. ${ }^{44}$ These legal acts may only be passed by law-making bodies that have been constitutionally empowered to do so. In turn, according to Article 91(3) of the Polish Constitution, if an agreement ratified by the Republic of Poland and establishing an international organization so provides, the laws it establishes apply directly and have precedence in the event of a conflict of laws. ${ }^{45}$ Terms

43 The Constitution of the Republic of Poland of 2 April 1997 (Journal of Laws of 1997, No. 78, item 483; and the amendments: Journal of Laws of 2001, No. 28, item 319; of 2006, No. 200, item 1471; of 2009, No. 114, item 946).

44 See the following judgements of the Constitutional Court: of 29 November 2017, case ref. P 9/15; of 6 December 2016, case ref. SK 7/15; of 10 February 2015, case ref. SK 50/13; of 12 December 2011, case ref. P 1/11; of 10 May 2005, case ref. SK 40/02; of 7 July 2003, case ref. SK 38/01; of 10 June 2003, case ref. SK 37/02.

45 See Judgement of the Constitutional Court of 12 December 2011, case ref. P 1/11. 
of use established for the operational purposes of digital platforms and social media certainly have nothing to do with generally applicable law in Poland. As such, they cannot autonomously lay down rights, obligations, or penalties, nor limit an individual's legally created rights. These documents can be issued, for example, in order to properly organize online communities, but if they introduce any restrictions on their users' rights and freedoms, they must comply with protection standards in this regard, for example, the standard of freedom of expression or pluralism that results from generally applicable law in Poland.

As the observation of the terms of use prevailing on the Internet demonstrates, this is generally not the case. The fact is that the current models of the control and restriction of Internet users' activities, including their publication of content, especially on political or moral grounds, arise from documents that have the character of internal rules. In principle, these documents make no reference to the Polish legal order, in particular due to the transnational nature of the activities of digital platforms or social media. This feature, however, cannot justify restrictions on the freedoms and rights of individuals on the Internet as provided for in the Polish normative system. All of this provides a typical example of unlawful censorship on the Internet. After all, an action contrary to such terms of use results in the removal of a post or temporary or permanent account suspension. On the other hand, if the user believes that the restriction they have suffered is unjustified, they may bring action before the courts to assert their rights and freedoms. For this reason, most terms of use specify the jurisdiction and governing law should a dispute arise. ${ }^{46}$

An analysis of this aspect can be applied to Facebook's terms of service, ${ }^{47}$ which the portal has officially translated into Polish and thus have been prepared for, apply to, and are accepted by Polish Internet users. This example is relevant and, as it seems, representative, since the majority of Polish citizens use this social network service. ${ }^{48}$ Incidentally, one can mention that the content of the terms is most likely the same for all Facebook users around the world. Section 3 of Facebook's terms of service sets out 'Your commitments to Facebook and our community.' For example, in accordance with item 2 of this section, 'What you can share and do on Facebook,' one of Facebook's objectives is to ensure that its users express themselves and share content that is important to them, but not at the expense of others' safety and wellbeing or the integrity of the Facebook community. For this reason, Facebook users may not use Facebook products to do or share anything that (a) breaches Facebook's terms, community standards, and other terms and policies that apply to use

46 In the context of special jurisdiction in cases of infringement of personal rights on the Internet, see: Judgement of the Court of Justice of the European Union of 17 October 2017 in case C-194/16 Bolagsupplysningen OÜ and Ingrid Ilsjan v Svensk Handel AB (ECLI:EU:C:2017:766); Judgement of the Court of Justice of the European Union of 25 October 2011 in joined cases C-509/09 and C-161/10 eDate Advertising GmbH and others v X and Société MGN LIMITED (ECLI:EU:C:2011:685).

47 Facebook Terms of Service, https://www.facebook.com/legal/terms.

48 According to the 'NapoleonCat' report of January 2021, Facebook is used by $57.2 \%$ of Poles (21,680,000 users). 
of Facebook; (b) is unlawful, misleading, discriminatory or fraudulent; or (c) infringes or breaches someone else's rights, including their intellectual property rights. In view of the above, Facebook can remove or block content when a Polish user breaches these provisions of the terms of service. Additionally, regardless of the above, Facebook may remove or restrict access to any user content, service, or information, including a user's account, if it deems such an action reasonably necessary to avoid or mitigate adverse legal or regulatory impacts to Facebook. In practice, this means that Facebook's terms of service authorize it to remove any content that it deems problematic.

In this context, inspired by Facebook's terms of service, the discussed issue can be considered in at least two categories from the perspective of the Polish normative system. The first one is where a social network service administrator censors content on legal grounds. This is, as noted before, lawful censorship, as it is based on generally applicable law in Poland. An example of this is the censorship of content on the Internet based on copyright, as presented above. The other category is where a social network service administrator censors content, especially on political or moral grounds, but on a basis different than generally applicable law in Poland. Such other basis often comes from the specific terms of a social network site's community. This is an example of unlawful censorship, the scale of which is much larger. The rules determining its application are not always clearly defined, or rather, they are treated as a specific empowerment of the website's owner, quite apart from the human rights system recognized in Poland and from the rights and freedoms that every individual enjoys regardless of where they perform their activities.

In view of the above, coupled with the fact that in Poland, there is currently no legal framework directly concerning either the legal status of digital platforms and social media or the sanctioning of unlawful censorship, one can conclude that this issue remains in a legal vacuum. In recognition of this, the Polish Ministry of Justice, on 22 January 2021, decided to apply to the Chancellery of the Prime Minister for the entry of a draft act on the protection of freedom of speech on social network sites ${ }^{49}$ (draft act on freedom of speech) on the list of the Council of Ministers' legislative works. This new legislative initiative appears to be a direct response to the existing regulatory gap. The message seems clear: Freedom of expression, speech, or pluralism is to be guaranteed regardless of the environment in which an individual is active, especially in the digital environment. Further, any restrictions on Polish Internet users' rights and freedoms must be normatively sanctioned.

According to the recitals of the draft act on freedom of speech, it is to be passed due to the special constitutional value of freedom of speech and with a view to strengthening this freedom's role in the search for truth, the functioning of a

49 Draft act on the protection of freedom of speech on social network sites (15 January 2021), https://www.gov.pl/web/sprawiedliwosc/zachecamy-do-zapoznania-sie-z-projektem-ustawy-o-ochronie-wolnosci-uzytkownikow-serwisow-spolecznosciowych. 
democratic state, and respect for the principle of freedom of expression and human dignity. The Polish Ministry of Justice has pointed out that under the new legislation, social network sites will not be able to remove posts or block Polish users' accounts if the content posted does not violate Polish law. ${ }^{50}$ This seems to be a basic rule that will entail severe administrative penalties if breached. The proposed legal act also aims to fill the above-indicated legal gap. The Polish Ministry of Justice has clearly confirmed this by stating that website administrators currently make independent decisions to remove posts and block user accounts, for which there is no effective remedy or appeal available, even if the user proves that they have not violated any law and that the website's action violates freedom of expression..$^{51}$ Another important objective of the draft act on freedom of speech is to ensure the effective right to truthful information and protect personal rights or interests infringed upon by anonymous Internet users. ${ }^{52}$

Pursuant to Article 1 of the draft act on freedom of speech, the objective of the document is, inter alia, to create conditions for supporting freedom of expression, improve the level of protection of human rights and freedoms on social network services made available in the territory of Poland with at least one million registered users, and uphold social network services' observance of the freedom of expression, the freedom to source and disseminate information, the freedom to express religious and philosophical views and beliefs, and the freedom of communication. The draft act on freedom of speech has a number of provisions aimed at achieving this goal. First, it defines the rules for controlling activities involving the provision of electronic services ${ }^{53}$ via online social network sites with at least one million registered users to the extent that public authorities are in a position to guarantee their users the right to freedom of expression. Second, it defines service providers' obligations as regards guarantees of the right to freedom of expression. Third, it lays down rules for internal audit and check processes to be performed by service providers with regard to user complaints concerning violations of the right to freedom of expression. Fourth, it contains provisions on proceedings before public administration

50 Ibid.

51 Ibid.

52 This issue will be discussed in a separate chapter of this monograph by Dr. hab. Marcin Wielec.

53 Pursuant to Article 2(4) of the Electronic Services Act of 18 July 2002 (consolidated text: Journal of Laws of 2020, item 344), provision of services electronically means rendering a service provided without simultaneous presence of the parties (remotely), by transmitting data at the individual request of the service recipient, as submitted and received by means of electronic processing devices, including digital compression and data storage, which are entirely issued, received or transmitted over an information and communications technology (ICT) network within the meaning of the Telecommunications Law Act of 16 July 2004 (consolidated text: Journal of Laws of 2021, item 576). In turn, pursuant to Article 2(35) thereof, an ICT network means transmission systems and switching or diverting devices, as well as other resources, including inactive network components, which enable the broadcast, reception, or transmission of signals by means of wired, radio, optic, or other means using electromagnetic energy, regardless of the kind. 
authorities and court actions in the event of the restriction of access to an electronic service provided via an online social network site.

The draft act on freedom of speech also intends to introduce a number of legal definitions into the Polish legal order. From the perspective of this study's subject matter, special attention should be paid to four definitions. The Polish Ministry of Justice proposed that the concept of an online social network service should be understood as an electronically provided service that allows users to share any content with other users or the general public and is used by at least one million registered users in the country. The definition of a user profile is also interesting, as it is intended to denote settings for social network service users' working environment. Currently, there are no such definitions in the Polish legal system. Nevertheless, from the point of view of the issue of unlawful censorship on digital platforms and social media, two other definitions are key, namely the legal definition of a limitation of access to content and a limitation of access to the user's profile. According to the draft act on freedom of speech, a limitation of access to content should be understood to cover all acts and omissions taken in any form with a view to limiting access to content posted on an online social network service, including by deleting user-posted content that is not illegal, ${ }^{54}$ and a limitation of access to content through the algorithms the service provider uses or tags, which indicate possible violations in the published content. Further, a limitation of access to the user's profile is meant to remove or prevent access to the user's profile, limiting or preventing content sharing with other users, including through the algorithms the service provider uses to limit the display of user-posted content or tags that indicate possible violations in the published content.

The above clearly demonstrates that the proposed regulation's material scope is extremely broad. In fact, these regulations are to be applied in practice to the functionalities of a substantial part of the Internet. It seems that, for this reason, the appointment of an appropriate public administration body is an inevitable consequence of adopting the legal regulations presented here. Therefore, the draft act on freedom of speech provides for the appointment of the Freedom of Speech Council (hereinafter 'the Council'), which is tasked with upholding social network services' observance of the freedom of expression, the freedom to source and disseminate information, the freedom to express religious and philosophical views and beliefs, and the freedom of communication. It is intended to be a key public administration body that can be understood as a control mechanism for ensuring that the proposed law is applied in practice. The Council is to have a six-year term of office, and its five-person panel is to comprise experts in the field of law and new media elected by the Sejm of the Republic of Poland by a 3/5 majority of votes, which essentially guarantees a

54 According to Article 3(8) of the draft act on freedom of speech, the term 'illegal content' is understood as content that violates personal rights, disinformation, content of criminal nature, as well as content that violates morality, especially by disseminating or praising violence, distress, or humiliation. 
multi-partisan and pluralist composition. ${ }^{55}$ Meetings of the Council are to be closed to the public, and the Council is to issue its decisions, rulings, and resolutions by a majority of votes by show of hands (open vote) with three members, including the chairman, in attendance. In the event of an equal number of votes, the chairman has the casting vote. The Council's decisions and rulings are to be final and valid.

The draft act on freedom of speech clearly emphasizes that a service provider ${ }^{56}$ is required to perform the obligations set out in the act, which is to become a universally binding law in Poland. First, it was decided that a service provider who receives over 100 user complaints in a calendar year regarding, inter alia, limited access to content or to users' profiles is obliged to prepare a semi-annual report in the Polish language concerning the resolution of such complaints and publish it on its social network site no later than one month after the end of a six-month period. Such reports published on an online social network site must be clearly visible and directly and permanently accessible. Regardless of this, such a service provider is obliged to file a request with the president of the Office of Electronic Communications ${ }^{57}$ (UKE) for the publication of its report in the Official Journal of the Office of Electronic Communications no later than one month after the end of a six-month period. Second, a service provider is required to appoint at least one, but not more than three, country representatives. The representatives' responsibilities would include representing the service provider in all judicial and extrajudicial actions, considering complaints during internal audit and check processes, providing responses and any information to institutions and authorities in relation to any conducted proceedings, and participating in training organized by the president of the UKE on the current legal status regarding complaints considered during internal audit and check processes. In view of the above, the draft act on freedom of speech assumes that a service provider is obliged to immediately inform the president of the UKE about the appointment or any changes to a country representative and provide their data, including their e-mail address and address for service. Where the country representative is a body corporate,,$^{58}$ a service provider provides the data of natural persons ${ }^{59}$ authorized to act on behalf of that body corporate. Service

55 https://www.gov.pl/web/sprawiedliwosc/zachecamy-do-zapoznania-sie-z-projektem-ustawy-o-ochronie-wolnosci-uzytkownikow-serwisow-spolecznosciowych.

56 According to Article 3(2) of the draft act on freedom of speech, the term 'service provider' means a provider of online social network services, consisting of the storage of information provided by the user on the online social network upon the user's their request and with at least one million registered users.

57 Pursuant to Article 3 of the Act of 29 December 2005 on transformations and changes in the division of responsibilities and powers of state bodies competent in the matters of communications and radio and television broadcasting, the president of the Office of Electronic Communications is a central body of government administration.

58 Pursuant to Article 33 of the Polish Civil Code (Civil Code Act of 23 April 1964 (consolidated text: Journal of Laws of 2020, item 1740, as amended), the State Treasury and organizational units granted a legal personality under specific provisions are bodies corporate.

59 Indirectly, pursuant to Article 8 of the Civil Code, a natural person is a person who has legal capacity from the moment of birth. 
providers' obligation to immediately inform the president of the UKE of any change in such details is a logical consequence. This is important because a service provider may not rely on a change of its country representative to bona fide third parties, public administration bodies, courts, and prosecutors' offices if the president of the UKE has not been notified and if the change has not been published on the social network site. A change of the country representative in the course of proceedings before public administration bodies, courts, and prosecutors' offices becomes effective upon notification. Information about the country representative is to be published on the social network site in a clearly visible, direct, and permanently accessible manner. On the one hand, such disclosure covers the country representative's full details, including their e-mail address and address for service, and if the country representative is a body corporate, the details of natural persons authorized to act on behalf of that body corporate must also be given. On the other hand, the service provider's full details will also be publicly available, including the full name of the entrepreneur running the social network site or their name and surname, registration or residence address, address for service, registration details, and e-mail address.

A completely different obligation on a service provider contained in the proposed law is to put in place, in the Polish language, effective and understandable internal audit and check processes in matters relating to user complaints concerning, inter alia, limited access to content and users' profiles. In this regard, a service provider is obliged to publish the social network site's terms of use in the Polish language and make it available to all users; the terms of use must contain the rules for conducting internal audit and check processes. The terms of use may not be in conflict with the provisions of generally applicable law in Poland. It should therefore not be surprising that in view of the above, a service provider is also obliged to ensure that complaints are sent for the internal audit and check process in a clearly visible and directly and permanently accessible manner. If a user files a complaint, the country representative is required to immediately send confirmation of receipt of the complaint to the e-mail address provided in the complaint. They consider the user's complaint and inform them of the outcome of such consideration via the indicated e-mail address within 48 hours of the filing of the complaint. If the complaint is accepted, the service provider restores the previously limited access to the content or to the user's profile. Information on the outcome of consideration of the complaint should include the reasons for the decision taken, indicating in particular the legal grounds with reference to the social network site's terms of use and the facts serving as the grounds for the decision, along with justification. The information must also contain instructions for exercising the option to file a complaint to the Council, as well as the date and method of the filing of the complaint. On the other hand, if the complaint is not accepted, the service provider informs the user about their option to pursue 


\section{their claims through civil action. ${ }^{60}$ The president of the UKE supervises the internal audit and check procedure.}

60 According to Article 38 of the draft act on freedom of speech: "In the Civil Procedure Code Act of 17 November 1964 (Journal of Laws of 2020, item 1575, 1578 and 2320 and of 2021, item 11), in the first part, in the first book, in title VII, in section VIII, after chapter 1, chapter 2 shall be added to read as follows: 'Chapter 2 Proceedings for the protection of personal rights against persons with unknown identity Article $505^{40}$. $\S 1$. The provisions of this chapter shall apply in cases regarding the protection of personal rights, if their violation occurred through the service provider within the meaning of the Electronic Services Act of 18 July 2002 (Journal of Laws of 2020, item 344), and the claimant does not know the first and last name or the name or address of the place of residence or registered office of the respondent who violated their personal rights. $\S 2$. The cases referred to in $\S 1$ are examined by the regional court competent for the place of residence or registered office of the claimant in the territory of the Republic of Poland. § 3. In the cases referred to in $\S 1$, in their claim, instead of the first and last name or the name or address of the place of residence or registered office of the respondent, the claimant provides information enabling the identification of the person who committed the violation, in particular the name of the user profile or login. Article $505^{41} \S 1$. The claim referred to in Article $505^{40} \S 3$ shall include: 1 ) an application for injunction by requiring the service provider referred to in Article $505^{40} \S 1$ to indicate the respondent's details specified in Article 18(1)-(5) of the Electronic Services Act of 18 July 2002 based on the information provided by the claimant; 2) the identification of the service provider referred to in Article $505^{40} \S 1$; 3 ) the indication of publications, in particular written messages, photos, audio and video recordings, which violate the personal rights of the claimant, with the URL of the online data resource on which these were published, the date and time of publication and the name of the user's profile or login, where possible; 4) the claimant's statement that they have attempted to notify the respondent of their intention to bring action against them or a statement that such notification was not possible, along with the reasons. $\S 2$. The claim must be accompanied by a clear reproduction of the publication referred to in $\S 1(3)$, in the form of an electronic record and in the form of a printout showing a copied screen image with a visible URL address and the date and time of publication. $\S 3$. The claim referred to in $\S 1$ may contain applications for injunction by: 1) preventing access to the publication, or 2) providing a notice indicating a contentious nature of the publication. Article $505^{42} \S 1$. The court shall dismiss the claim if: 1) the claim is manifestly unfounded; 2) the action violates the principles of social coexistence or aims to circumvent the law, in particular the provisions of the Personal Data Protection Act of 10 May 2018 (Journal of Laws of 2019, item 1781). § 2. The court shall dismiss the claim in closed session. § 3 . The justification of the decision shall be made ex officio in writing. It shall only contain an explanation as to why the claim was considered manifestly unfounded or violates the principles of social coexistence or aims to circumvent the law, in particular the provisions of the Personal Data Protection Act of 10 May 2018. The decision, along with the justification, shall be delivered by the court ex officio only to the claimant, with an instruction on the manner and time limit for filing an appeal. Article $505^{43} \S 1$. The court shall request the service provider to send in the data referred to in Article $505^{41} \S 1(1)$. $\S 2$. The court shall discontinue the proceedings if the service provider fails to send in the data referred to in Article $505^{41} \S 1$ (1) within 3 months of the delivery of the court's request for data. The decision shall be served only on the claimant. The decision shall be accompanied by an instruction on the option to bring action under generally applicable laws and regulations. § 3 . The claimant may file a complaint to any such decision. § 4 . The complaint shall be examined by the court which issued the challenged decision, sitting in a bench of three judges. $\S 5$. If the service provider has failed to send in the data referred to in Article $505^{41} \S 1$ (1) without justified reasons, the court shall sentence them to a fine according to the provisions on penalties for a witness' failure to attend. Where the service provider is a body corporate or an organizational unit, a fine shall be imposed on the manager or employee responsible for fulfilling the obligation to provide the data. Article $505^{44}$. The court shall examine the case according to the general provisions after the service provider has sent in the data referred to in Article $505^{41} \S 1(1) . "$ 
The draft act on freedom of speech also sets out the procedure before the Council. A user who is dissatisfied with the decision made regarding their complaint during the internal audit and check process may submit a complaint to the Council within seven days of receiving information about the outcome of the consideration of their complaint. The user files a complaint with the Council, along with information about the decision on the complaint filed with the service provider and confirmation of receipt thereof in the form of an electronic document uploaded to the public administration services' electronic platform. ${ }^{61}$ The complaint is to be signed by the party or its statutory representative or proxy with a qualified electronic signature, a trusted signature, or a personal signature. Upon the ineffective expiry of the time limit for consideration of the complaint under the internal audit and check process, the user may file a complaint with the Council without attaching information about the decision on the complaint filed with the service provider. The complaint filed with the Council must include the first and last name or the name of the complainant and their legal representative or proxy, if appointed; identification of the service provider and its country representative; a description of the violation; and indication of the request. The parties to the proceedings before the Council are the user whose access to content was limited or the user whose access to their profile was limited and the service provider. Importantly, during the proceedings before the Council, the service provider acts through its country representative. Where a complaint has been filed, the Council will immediately notify the country representative of the user's complaint. The country representative provides the Council with the materials collected during the internal audit and check process within 24 hours of notification of the complaint filed by the user. What is crucial, as a result of the conducted proceedings, is that the Council issues a decision in which it either orders the restoration of the previously limited access to content or to the user's profile, if it finds that the content or user profile to which access was limited does not constitute illegal content, ${ }^{62}$ or it refuses to restore the previously limited access to the content or to the user's profile, if it finds that the content or user's profile to which access was limited constitutes illegal content. It should be noted that the above-indicated feature of illegality refers to a violation of Polish law. The Council issues a decision within seven days of the date of receipt of the complaint.

The evidence taken before the Council is limited to the evidence the user provided with the complaint, evidence provided by the country representative, and evidence that can be ascertained on the basis of the data available to the Council

61 Pursuant to Article 3 of the Act of 17 February 2005 on the computerization of the activities of entities performing public tasks (consolidated text: Journal of Laws of 2021, item 670), an electronic platform of public administration services is an ICT system in which public institutions provide services through a single access point on the Internet.

62 As a reminder, according to Article 3(8) of the draft act on freedom of speech, the term 'illegal content' is understood as content that violates personal rights, disinformation, or content of criminal nature, as well as content that violates morality, in particular, by disseminating or praising violence, distress, or humiliation. 
itself. The Council does not take evidence from the testimony of witnesses, hearing of the parties, expert opinions, or site inspections. It should be noted that of great importance here will be the use of electronic evidence, which has traditionally been used in civil proceedings, for example, to support the material circumstances of infringement on personal rights on the Internet, ${ }^{63}$ and in criminal proceedings, for example, to combat cybercrime. ${ }^{64}$ In this case, however, its potential will be used to prove the occurrence of unlawful censorship on the Internet affecting Polish users. In view of the above, a user is obliged to present all the evidence at the latest upon filing the complaint, under pain of losing the right to present such evidence in the course of further proceedings. Evidence submitted in breach of this obligation is disregarded, unless the party substantiates that its submission in the complaint was not possible. The Council disregards any evidence that would lead to an extension of the proceedings. On the other hand, the justification of the decision issued in the proceedings before the Council may be limited to indicating the facts which the Council considers proven and quoting the legal provisions constituting the legal basis for the decision. The Council delivers the decision to the parties immediately, no later than within 24 hours of issuance, and the service provider is required to execute the Council's decision immediately, no later than within 24 hours of delivery. Within another 24 hours from the expiry of the time limit for the execution of the decision, the country representative informs the Council about the manner of performance. If the service provider fails to comply with the decision, the Council immediately notifies the president of the UKE. Importantly, the service provider cannot once again limit access to content that was the subject of examination before the Council.

The draft act on freedom of speech also provides for numerous administrative penalties in the event of failure by a service provider or its country representative to comply with the obligations set out in this proposed legislation. For example, a service provider who, inter alia, fails to fulfil the obligation to submit the report; appoint the country representative; immediately notify the president of the UKE of the appointment or change of its country representative or provide their details; put in place an effective and understandable internal audit and check process in the Polish language; post the social network site's terms of use, including the internal audit and check process, on the site in the Polish language so that it is available to all users; provide a clearly visible and directly and permanently available mechanism for submitting complaints through the internal audit and check process; or implement any

63 Judgement of the Court of Justice of the European Union of 17 October 2017 in case C-194/16...; Judgement of the Court of Justice of the European Union of 25 October 2011 in joined cases C-509/09 and C-161/10...

64 For example, see: Gercke, 2004, p. 802; Winick, 1994, pp. 75-128; Katyal, 2001, pp. 1003-1114; Marion, 1997, pp. 67-108; Silver, 2001, p. 5; Sinrod and Reilly, 2000, pp. 1-53; Speer, 2000, pp. 259-273; Gercke, 2009, pp. 409-420; Brenner and Schwerha, 2004, pp. 111-114; Hilley, 2005, pp. 171-174; Walden, 2004, pp. 321-336; Moitra, 2005, pp. 435-464; Wang, 2007, pp. 216-223; Nuth, 2008, pp. 437-446; Chung et al., 2006, pp. 669-682; Boni, 2001, pp. 18-19; Clough, 2014, pp. 698-736. 
Council decision to restore previously limited access to content or to a user's profile is liable to a financial penalty. Further, a service provider is liable to a financial penalty for its country representative's failure to fulfil the obligation to consider a user complaint filed under the internal audit and check process, provide responses and any information to institutions and authorities in relation to any conducted proceedings, or participate in training organized by the president of the UKE on the current legal status regarding complaints considered through the internal audit and check process. For the service provider's breach of each of these obligations, the Council imposes, by way of a decision, a financial penalty in the amount of PLN 50,000 to PLN 50,000,000. When imposing a financial penalty, the Council considers the impact of the service provider's omission on the magnitude of disinformation caused, the degree of breach of the public interest, the frequency of past breaches of an obligation or breaches of a prohibition of the same type as the breach of the present obligation or breach of prohibition as a result of which the penalty is to be imposed, and the past record of penalties for the same conduct and actions voluntarily taken by the party to avoid the consequences of a violation of the law. A party dissatisfied with a Council decision may apply to the Council for reconsideration of the case, so it does not have a right to appeal. ${ }^{65}$

The above is a presentation of the scope of the regulations contained in the draft act on freedom of speech with regard to the issue signaled in the title, i.e., issues of unlawful censorship. Nevertheless, it should be clearly noted that this draft legal act also has another dimension, which is to prevent and combat false information posted on the Internet, for example, for the purpose of disinformation or discrediting. This is an important issue that will be discussed in another chapter in this monograph. With regard to the issue of censorship, it is clear that the main objective of the draft act on freedom of speech is to counteract and combat unlawful censorship. The above-presented regulations apply to it. It is the main problem that the proposed legislation is supposed to solve. This is because lawful censorship, as one sanctioned in generally applicable law in Poland, does not fall within the scope of the application of the draft act on freedom of speech. Therefore, the example of censorship under copyright laws in Poland has a completely different legal status.

Certainly, the fact that a draft act on freedom of speech has been proposed for adoption in Poland as universally binding law should be assessed in very positive terms. Lawyers, both scholars and practitioners, cannot deny the threats resulting from the current technical, technological, and civilizational progress. It is a matter of a simple causal relationship. Since a new level of human activity has emerged in

65 As a rule, pursuant to Article $127 \S 1$ of the Code of Administrative Procedure (Code of Administrative Procedure Act of 14 June 1960 (consolidated text: Journal of Laws of 2021, item 735)), a party may appeal against a decision issued in the first instance on one occasion only. On the other hand, pursuant to $\S 3$ of the same provision, a decision issued in the first instance by a minister or a local government court of appeals is not subject to appeal; however, a party who is dissatisfied with the decision may apply to that body for reconsideration of the case, and the provisions on appeals against decisions will apply mutatis mutandis to that application. 
the form of cyberspace, we must be aware that cybercrime is concomitant. Since cybercrime is emerging, we should introduce legal regulations regarding electronic evidence and technologically advanced evidence taking. This is exactly the case with the subject indicated in the title. Since the Internet appears to have become a new and increasingly popular space for human activity, we must be aware that numerous threats to individual rights and freedoms will also arise. Online censorship is one such threat. Since there is a phenomenon of censorship on the Internet, we must be aware of it and be in a position to distinguish between lawful and unlawful censorship. Since we can see and understand unlawful censorship on the Internet, we can counteract it by introducing a law such as the draft act on freedom of speech in Poland.

The quality of the proposed law deserves high praise. The regulation is comprehensible, transparent and, in principle, unconditional. Thus, alongside professional lawyers, average users will also understand the proposed principles of freedom of speech on the Internet. This is what law should be about in the first place. Second, it should be noted that although there has not yet been an opportunity to test this legislation in practice, it seems to be adequate and justified. It is adequate, meaning it does not go beyond what is necessary, and it protects what is necessary. For example, the administrative penalty range is from PLN 50,000 to PLN 50,000,000, which is wide enough to correspond to the variety of digital platforms and social media on the Internet. Furthermore, the legislation protects individuals' freedoms and rights, which in themselves entail a need for protection. On the other hand, it is justified in that it responds to the actual phenomenon of unlawful censorship, which must be counteracted in line with the essence of the rights and freedoms of every human being, as universally recognized in all civilized countries in today's world. Equally important is the fact that the legal norms contained in the draft act on freedom of speech, by filling the regulatory gap, have systemic consistency with other legal acts in force in Poland. There seems to be no contradiction or logical inconsistency between them, especially due to the fact that the proposed law adapts the wording of other legal acts that are generally applicable in Poland. ${ }^{66}$ Consequently, the assessment of systemic compatibility is satisfactory. Ultimately, the axiology of law is also important. The draft act on freedom of speech is an equitable law, based on the principle of justice, including social justice, and it strives to implement the value of truth, ${ }^{67}$ duly taking account of the dignity of every human being, which is the source of their rights and freedoms, and introducing justified controls on the Internet.

66 For example, according to Article 39 of the draft act on freedom of speech, "in the Act of 31 July 1981 on the remuneration of persons holding state managerial positions (Journal of Laws of 2020, item 1637) in Article 2(4), after the words 'a member of the State Commission for the investigation of cases of acts against sexual freedom and morals towards a minor under the age of 15,' the words 'a member of the Freedom of Speech Council' shall be added."

67 See Wielec, 2017, pp. 149-277; Judycki, 2001, pp. 25-26; Zajadło, 2013, pp. 20-32; Waltoś, 2014, pp. 273-281; Jodłowski, 2015, pp. 54-71; Dębowski, 2014, pp. 12-15; Strogowicz, 1959, p. 85; Murzynowski, 1976, p. 131; Jabłońska-Bonca, 1999, p. 80; Klejnowska, Kłak, and Sobolewski, 2011, p. 45; Dyl A. et al., 2012, pp. 23-24. 
To summarize, the draft act on freedom of speech proposed by the Polish Ministry of Justice consists of a number of provisions protecting freedom of speech against unlawful censorship on the Internet. It defines the rules for controlling activities involving the provision of electronic services via social network sites. It defines service providers' obligations as regards the guarantees of the right to freedom of expression. It lays down rules for internal audit and check processes to be performed by service providers with regard to user complaints concerning violations of the right to freedom of expression. It contains provisions on proceedings before public administration authorities and court actions in the event of restriction of access to an electronic service provided via an online social network site. It also provides for sanctions. Taking all the reasons cited above into account, the law's motives are highly rated. This law is Poland's response to unlawful censorship on the Internet and may serve as a model for imitation or inspiration for other countries, not only in Europe, but in general.

\section{Freedom of speech and pluralism in Poland}

In Poland, freedom of speech and pluralism are respected as individuals' constitutionally guaranteed rights and freedoms. Pursuant to Article 14 of the Polish Constitution, Poland ensures freedom of the press and other means of social communication. Pursuant to Article 49 of the Polish Constitution, the freedom and privacy of communication are ensured. Any limitation thereon may be imposed only in cases and in a manner specified by statute. Pursuant to Article 53 of the Polish Constitution, freedom of conscience and religion shall be ensured to everyone. Freedom of religion includes the freedom to profess or to accept a religion by personal choice as well as to manifest such religion, either individually or collectively, publicly or privately, by worshipping, praying, participating in ceremonies, and performing rites or teaching. Freedom of religion also includes possession of sanctuaries and other places of worship for the satisfaction of believers' needs, as well as the right of individuals, wherever they may be, to benefit from religious services. In this context, parents have the right to ensure their children a moral and religious upbringing and teaching in accordance with their convictions. ${ }^{68}$ The religion of a church or other legally recognized religious organization may be taught in schools, but other peoples' freedom of religion and conscience may not be infringed thereby. The freedom to publicly express religion may be limited only by means of statute and only where

68 In this case, the provision of Article 48(1) of the Polish Constitution applies mutatis mutandis. According to it, parents have the right to rear their children in accordance with their own convictions. Such upbringing should respect the child's degree of maturity as well as their freedom of conscience and belief and also their convictions. 
this is necessary for the defense of state security, public order, health, morals, or the freedoms and rights of others. No one may be compelled to participate or refrain from participating in religious practices. No one may be compelled by organs of public authority to disclose their philosophy of life, religious convictions, or belief. Pursuant to Article 54 of the Polish Constitution, the freedom to express opinions and acquire and disseminate information is ensured to everyone. Preventive censorship of the means of social communication and the licensing of the press are prohibited. Statutes may require the receipt of a permit for the operation of a radio or television station. Pursuant to Article 73 of the Polish Constitution, the freedom of artistic creation and scientific research, as well as dissemination of the fruits thereof, and the freedom to teach and enjoy the products of culture are ensured to everyone.

In the opinion of the Polish Constitutional Court (CC), freedom of speech covers all levels of an individual's activity, is an expression of the dignity of a person's autonomy, and creates opportunities for full personality development in the individual's cultural and civilizational environment. ${ }^{69}$ However, the most important thing in the context of the subject matter covered in the title is the correct understanding of the normative content of Article 54 of the Polish Constitution. One of the CC's rulings $^{70}$ underlined that Article 54(2) of the Polish Constitution states that "preventive censorship of the means of social communication and the licensing of the press are prohibited." It noted that the provision contains an absolute norm related to the essence of freedom of all expression in these domains. The Court concluded that the prohibition of the licensing of the press is closely related to the need to make freedom of speech a reality. It pointed out that it is rightly emphasized in the doctrine that the effective pursuit of the freedom of the press must be based on the principle of freedom and the liberal model, while any prevention based on censorship or prior authorization is incompatible with these ideas. ${ }^{71}$ In this regard, it stressed that censorship or a preventive system of press control interferes with the essence of the constitutional freedom of expression by means of social communication. The key point, however, is that in its ruling, the CC interpreted the normative content of Article 54 of the Polish Constitution. By comparing the meaning of Article 54 of the Polish Constitution and Article 10 of the Convention for the Protection of Human Rights and Fundamental Freedoms (ECHR), ${ }^{72}$ it indicated that the former's meaning is narrower than that provided for in the latter. According to the CC, this is so because Article 10 of the ECHR concerns the freedom of all expression, which covers not only the expression of views through speech, but also in written, printed, or artistic form. Further, the presented ruling stressed that Article 54 of the Polish Constitution provides for the freedom to express one's views and to source and

69 Judgement of the Constitutional Court of 12 May 2008, case ref. SK 43/05; Judgement of the Constitutional Court of 14 December 2011, case ref. SK 42/09.

70 Judgement of the Constitutional Court of 20 February 2007, case ref. P 1/06.

71 Cited from the CC: J. Israel, Droit des libertés fondamentales (Paris: éd. L.G.D.J.,1988), p. 463.

72 Convention for the Protection of Human Rights and Fundamental Freedoms (4 November 1950, as amended), (Polish Journal of Laws of 1993, No. 61, item 284). 
disseminate information in verbal, written, and printed form, including through any means of social communication. Moving on to the key conclusion, the CC stated that the acquisition and dissemination of information referred to in Article 54 of the Constitution comprise not only the freedom to source and disseminate facts, but also the views and opinions of others. Therefore, in its opinion, the normative content of Article 54 of the Polish Constitution is contained in the democratic standard of freedom of expression as defined today, and in particular, in the generally defined Article 10 of the ECHR.

In its entirety, the above argument clearly demonstrates that freedom of expression is provided for in the Polish Constitution, while the same legal norms contain the principle of pluralism in this respect. However, this was not achieved in a single provision, but in many. Only a comparison of Articles 14, 49, 53, 54, and 73 of the Polish Constitution, with their proper interpretation, in particular of Article 54, confirms this conclusion. Therefore, it should not be surprising that, in accordance with Polish law, it is only admissible to limit these individual rights and freedoms in such a way that does not infringe on their essence. The normative basis for any such limitation is provided for in Article 31(3) of the Polish Constitution. Pursuant to this provision, any limitation upon the exercise of constitutional freedoms and rights may be imposed only by statute and only when necessary in a democratic state for the protection of its security or public order or to protect the natural environment, health, or public morals, or the freedoms and rights of other persons. These limitations may not infringe on the substance of the freedoms and rights. The scope of Article 31(3) of the Polish Constitution is universal, as it applies to all freedoms and rights guaranteed in the Constitution. ${ }^{73}$ In the CC's opinion, the principle of proportionality dictates: the application of measures that enable the effective achievement of the intended objectives; the application of only necessary measures, i.e., measures that are the least burdensome for the individual; and the maintenance of an appropriate balance between the benefit of the measures applied and the burden imposed on the individual. ${ }^{74}$ Thus, any provision introducing a limitation is inconsistent with the Polish Constitution if the same effects could be achieved by means that restrict the exercise of personal freedoms or rights to a lesser extent. ${ }^{75}$ This means that in Poland, the limitations under Articles 14, 49, 53, 54, and 73 of the Polish Constitution may be imposed, but solely on strictly defined principles resulting from Article 31(3) of the Polish Constitution. These principles fall into two dimensions. The formal dimension requires that the limitations be introduced in the form of a statute (act), and the material dimension requires that they be necessary in a democratic state for the protection of its security or public order, or to protect the natural environment,

73 Judgement of the Constitutional Court of 26 May 2008, case ref. SK 25/07.

74 Judgement of the Constitutional Court of 28 June 2000, case ref. K 34/99; Judgement of the Constitutional Court of 29 September 2008, case ref. SK 52/05.

75 Judgement of the Constitutional Court of 30 October 2006, case ref. P 10/06. 
health, or public morals, or the freedoms and rights of other persons. Both of these dimensions must be met jointly.

\section{Conclusions}

It should be noted that law undergoes substantial changes. It is clear that not only the legislation is subject to change, but also its interpretation. It seems that it is equally clear that reality can be ahead of law and thus force the introduction of new legislation. This is precisely the case, for both aspects, with the subject indicated in the title. First, as a result of CJEU case law, the construction of Article 3(1) of Directive 2001/29/EC has been altered. Second, the fact of controlling and limiting Internet users' activities, including their publication of content, in particular on political or moral grounds but not legal grounds, forces the wise legislator to take appropriate, targeted, and effective legislative action. In order to determine whether the analyzed cases and forms of censorship represent limitations under the principles provided for in Article 31(3) of the Polish Constitution, it is necessary to determine whether they meet the formal and material aspects of this legal norm.

Lawful censorship constitutes a direct restriction of the rights and freedoms provided for in the Polish Constitution. The presented example of such censorship results from the implementation of Article 3(1) of Directive 2001/29/EC in the Polish normative system. This transposition of EU law was made in the form of a statute (act). This means that the formal aspect of Article 31(3) of the Polish Constitution was followed correctly. Incidentally and to signal an issue, an interesting thing here is the problem of the CJEU's subsequent modification of the normative meaning of Article 3(1) of Directive 2001/29/EC in the context of the requirement to keep the statutory form for restrictions on individual rights and freedoms in Poland. At this point, however, one cannot but assume that the CJEU decoded the proper meaning of the EU concept of 'communication to the public' without creating new standards, to only present those that are not visible at first sight in the content of the provision, being hidden in the essence of the legal norm. In this situation, it is crucial to determine whether Article 3(1) of Directive 2001/29/EC, as implemented in the Polish legal system and then enriched with the CJEU's autonomous constructions, meets the requirements of the material aspects of Article 31(3) of the Polish Constitution, that is, whether such a system of the admissibility of posting content on the Internet through the perspective of copyright laws is necessary in a democratic state for the protection of its security or public order, or to protect the natural environment, health, or public morals, or the freedoms and rights of other persons. Obviously, copyright protection is about others' freedoms and rights, that is, the copyright holder's legitimate claims. Nevertheless, as indicated above, these restrictions may not infringe on the essence of other freedoms and rights. Therefore, for them to be 
considered reasonable, justified, and lawful, one must first determine whether the restrictions enable the effective achievement of the objectives pursued. It seems that the system for the admissibility of hyperlinking, as defined by the CJEU, ensures full achievement of the objectives set, i.e., copyright protection on the Internet. Second and third, one should examine whether such stringently defined hyperlinking rules constitute a necessary measure, i.e., the least burdensome to an individual out of the available measures, and whether an appropriate proportion was maintained between the benefit of the measures applied and the burden imposed on an individual. Over these points, the answer is not so obvious and requires an in-depth and multi-contextual analysis, that is, an analysis that will not focus on generalities, but will examine each CJEU ruling separately. However, this requires a much broader scholarly presentation. At present, what can be stated with certainty is that the conditions of compatibility assessment will follow different paths for the judgements in the GS Media case and related rulings, and for the judgements in the Renckhoff case and related rulings. These are clearly separate groups of judgements.

In the case of unlawful censorship, it is obvious that it openly violates and restricts the individual rights and freedoms provided in the Polish Constitution. This is one of two indisputable facts. The other one is that it has no basis in generally applicable law in Poland. This means that, from the outset, this type of censorship does not meet the requirements of the formal aspect of Article 31(3) of the Polish Constitution. The conclusion is therefore that unlawful censorship constitutes a limitation-without a legal sanction-of the individual rights and freedoms provided in the Polish Constitution. In this context, the Polish draft act on freedom of speech should be treated as a wise response to this negative phenomenon that has emerged and is growing on the Internet.

The protection of freedom of expression and the preservation of pluralism on the Internet constitute a new objective in law for the contemporary legislator. It is an opportunity to preserve the standards of human rights protection developed over the years in the real world in the realm of the digital world. After all, to opt for progress does not mean forgetting the human values, ideals, or principles universally recognized by civilized nations. Otherwise, the progress is spurious. 


\section{Bibliography}

Afsarmanesh, H., Masís, V., Hertzberger, L. (2004) 'Virtual Community Support in Telecare' in Camarinha-Matos, L., Afsarmanesh, H. (eds.) Processes and Foundations for Virtual Organizations: IFIP TC5/WG5.5 4th Working Conference on Virtual Enterprises, PRO-VE 2003. Boston, Springer, pp. 211-220.

ANDRÉ, A. (2019) 'The Information Technology Revolution in Health Care' in André A. (ed.) Digital Medicine. Health Informatics. Cham: Springer, p. 4.

BonI, B. 'Creating a Global Consensus Against Cyber Crime', Network Security, 2001/9, pp. 18-19.

BRENNER, S., SCHWERHA, J. (2004) 'Introduction-Cybercrime: A Note on International Issues', Information Systems Frontiers, 6(2), pp. 111-114.

Chung, W., Chen, H., Chang, W., Chou, S. 'Fighting Cyber Crime: A Review and the Taiwan Experience', Decision Support Systems, 2006/41, pp. 669-682.

Clough, J. (2014) 'A World of Difference: The Budapest Convention on Cybercrime and the Challenges of Harmonization', Monash University Law Review, 40(3), pp. 698-736.

Colangelo, G., Maggiolino, M. 'ISPs' Copyright Liability in the EU Digital Single Market Strategy', International Journal of Law and Information Technology, 2018/3, pp. 142-159.

DE Pietro, C., Francetic, I. (2018) 'E-health in Switzerland: The Laborious Adoption of the Federal Law on Electronic Health Records (EHR) and Health Information Exchange (HIE) Networks', Health Policy, 122(2), pp. 69-74.

DĘBOWSKI, J. (2014) 'O klasycznej koncepcji prawdy i jej filozoficznych podstawach. Czy w Matrixie możliwa jest prawda?’ in Kilkiewicz, A., Starzyńska-Kościuszko, E. (ed.) Oblicza prawdy $w$ filozofii, kulturze, języku. Olsztyn: Instytut Filozofii Uniwersytetu WarmińskoMazurskiego, pp. 12-15.

Doroszewski, W. (ed.) Słownik Języka Polskiego [Online]. Available at: https://sjp.pwn.pl/ doroszewski/cenzura;5416093.html (Accessed: 15 May 2021).

Držanič, I., Mladenović, V., Debevc, M., Dolničar, V., Petrovčič, A., Touzery, S., KožUH, I. (2019) 'Usability Testing of a Smartphone Telecare Application for Informal Caregivers' in Milošević, D., Tang, Y., Zu Q. (eds.) Human Centered Computing: 5th International Conference, HCC 2019. Cham, Springer, p. 252.

DutTon, W. 'Internet Studies: Foundations of a Transformative Field' in Dutton, W. (ed.) The Oxford Handbook of Internet Studies. Oxford: Oxford University Press, 2013, p. 1.

DYL, A., DYL, K., MiĘTKOWSKA, K., TOKARZ, A. Procedura karna. Repetytorium. Warszawa: Wolters Kluwer, 2012, 23-24.

Elenko, E., Underwood, L., ZoHAR, D. (2015) 'Defining Digital Medicine', Nature Biotechnology, 33(5), pp. 456-461.

Eurostat (25 May 2021) 'Individuals - internet use'. Available at: https://ec.europa.eu/eurostat/ databrowser/view/isoc_ci_ifp_iu/default/table?lang=en (Accessed: 20 April 2021).

Facebook Terms of Service [Online]. Available at: https://www.facebook.com/legal/terms (Accessed: 20 May 2021).

FERNÁNDEZ-DíEZ, I. 'La puesta a disposición de obras y prestaciones protegidas por quien no tiene la autorización de los titulares de derechos de propiedad intelectual cuando previamente se ha hecho accesible dicha obra en Internet con licencia del autor', La Ley Unión Europea, 2018/64, p. 2. 
GAO, X., Lin, L., Lan, T., Gan, X. (2020) 'Design and Research on the Chinese Medicine Health Management System Based on the Wireless Sensor Network' in Xu, Z., Choo, K., Dehghantanha, A., Parizi, R., Hammoudeh, M. (eds.) Cyber Security Intelligence and Analytics. Advances in Intelligent Systems and Computing 928. Cham, Springer, pp. 55-56.

GERCKE, M. 'Europe's Legal Approaches to Cybercrime', ERA Forum, 2009/10, pp. 409-420.

GERCKE, M. 'Analyse des Umsetzungsbedarfs der Cybercrime Konvention. Teil 2: die Umsetzung im Bereich des Strafverfahrensrechts', Multimedia und Recht, 2004/12, pp. 801-806.

GinsBuRG, J. (2017) 'The Court of Justice of the European Union Creates an EU Law of Liability for Facilitation of Copyright Infringement: Observations on Brein v. Filmspeler [C-527/15] (2017) and Brein v. Ziggo [C-610/15] (2017)' Columbia Law and Economics Working Paper 572.

HeLIOS, J. Jedlecka W. (2018) Wykładnia prawa Unii Europejskiej ze stanowiska teorii prawa. Wrocław: Wydział Prawa, Administracji i Ekonomii Uniwersytetu Wrocławskiego.

HILlEy, S. 'Pressure Mounts on US Senate to Pass Cybercrime Treaty', Digital Investigation, 2005/2, pp. 171-174.

HuANG, C. (2009) 'Medical Informatics' in Nof, S. (ed.) Springer Handbook of Automation. Berlin: Springer, 1423-1432.

Istepanian, R., LAXMinarayan, S., PATtichis, C. (eds.) (2006) Preface in M-Health. Emerging Mobile Health System. Cham, Springer.

JABŁOŃSKA-BONCA, J. (1999) O prawie, prawdzie i przekonywaniu. Koszalin: Wydawnictwo Uczelniane Bałtyckiej Wyższej Szkoły Humanistycznej.

JoDŁOWSKI, J. Zasada prawdy materialnej $w$ postępowaniu karnym. Analiza $w$ perspektywie funkcji prawa karnego. Warszawa, 2015, pp. 54-71.

JUDYCKI, S. (2001) 'O klasycznym pojęciu prawdy', Roczniki Filozoficzne, 49(1), pp. 25-62.

KATYAL, N. (2001) 'Criminal Law in Cyberspace', University of Pennsylvania Law Review, 149(4), pp. 1003-1114.

KlaR, R., Pelikan, E. (2011) 'Telemedicine in Germany' in Kramme, R., Hoffmann, K., Pozos R. (eds.) Springer Handbook of Medical Technology. Berlin: Springer, 1119-1127.

KlejnowskA, M., KŁAK, C., Sobolewski, Z. (2011) Proces karny. Część ogólna. Warszawa: Wolters Kluwer.

Koo, J. (2018) 'Away We Ziggo: The Latest Chapter in the EU Communication to the Public Story', Journal of Intellectual Property Law \& Practice, 13(7), pp. 542-551.

LINKous, J. (2001) 'A Rapidly Evolving Definition of Telemedicine' in Kiel J. (ed.) Information Technology for the Practicing Physician. Health Informatics. New York: Springer, p. 226.

LONG, J. (2018) 'Different Solutions for Similar Questions: Hyperlinks and the Right of Communication to the Public in China and the EU', International Review of Intellectual Property and Competition Law, 49, pp. 413-435.

LuPTON, D. (2013) 'The Digitally Engaged Patient: Self-Monitoring and Self-Care in the Digital Health Era', Social Theory \& Health, 11(3), pp. 256-270.

Maimone, A., Bidwell, J., Peng, K., Fuchs, H. (2012) 'Augmented Reality: Enhanced Personal Autostereoscopic Telepresence System Using Commodity Depth Cameras', Computers \& Graphics, 36(7), pp. 791-807.

MARION, N. (1997) 'Symbolic Policies in Clinton's Crime Control Agenda', Buffalo Criminal Law Review, 1(1), pp. 67-108.

MARs, M., ScOTt, R. (2010) 'Global E-health Policy: A Work in Progress', Health Affairs, 29(2), pp. 237-243. 
Moitra, S. (2005) 'Developing Policies for Cybercrime', European Journal of Crime, Criminal Law and Criminal Justice, 13(3), pp. 435-464.

MURZYNOWSKI, A. Istota i zasady procesu karnego. Warszawa: PWN, 1976.

NORDEMANN, J. (2018) 'Recent CJEU Case Law on Communication to the Public and Its Application in Germany: A New EU Concept of Liability', Journal of Intellectual Property Law \& Practice, 13(9), pp. 744-756.

Nuth, M. (2008) 'Taking Advantage of New Technologies: For and Against Crime Computer Law and Security Report', Computer Law \& Security Review, 24(5), pp. 437-446.

ORĘZIAK, B. (2017) 'Judgment of the Court of Justice of the European Union (Second Chamber) of 8 September 2016 in Case C 160/15 in the proceedings of GS Media v Sanoma Media Netherlands BV, Playboy Enterprises International Inc., Britt Geertruid Dekker', Comparative Law Review, 23(1), pp. 243-253.

OrĘZIAK, B. (2018a) 'Czy linkowanie w sieci jest dopuszczalne? Analiza w świetle najnowszego orzecznictwa Trybunału Sprawiedliwości Unii Europejskiej’ in Żak D. (ed.) Własność intelektualna $w$ Internecie. Lublin: Towarzystwo Naukowe KUL, Katolicki Uniwersytet Lubelski, pp. 137-157.

ORĘZIAK, B. 'Ograniczenia linkowania w Internecie w świetle orzecznictwa Trybunału Sprawiedliwości Unii Europejskiej - analiza orzeczenia z dnia 14 czerwca 2017 roku w sprawie C-610/15', Przegląd Prawno-Ekonomiczny, 2018b/4, pp. 199-219.

ORĘZIAK, B. 'Analiza prawnej dopuszczalności zamieszczania hiperlinków w internecie. Uwagi na tle wyroku Europejskiego Trybunału Praw Człowieka z 4.12. 2018 r. w sprawie MAGYAR JETI ZRT przeciwko Węgrom', Prawo w Działaniu Sprawy Cywilne, 2019a/40, pp. 181-192.

ORĘZIAK, B. (2019b) 'Judicial Dialogue between the European Court of Human Rights and the Court of Justice of the European Union in the Field of Legal Liability for Posting Hyperlinks', International Community Law Review, 21(5), pp. 432-448.

Paglialonga, A., Mastropietro, A., Scalco, E., Rizzo, G. (2019) 'The mHealth' in Andreoni, G., Perego, P., Frumento, E. (eds.) $m_{-}$Health Current and Future Applications. Cham: Springer, pp. 5-17.

RAdosavlJEV, P. (2017) 'For Whom the Copyright Scale Tips: Has the CJEU Established a Proper Balance of Rights with Its GS Media Case Judgement?', European Journal of Law and Technology, 8(3).

RADZIEWICZ, P. 'Wzruszenie "domniemania konstytucyjności" aktu normatywnego przez Trybunał Konstytucyjny’, Przegląd Sejmowy, 2008/5, pp. 55-86.

RosATI, E. (2017) 'GS Media and Its Implications for the Construction of the Right of Communication to the Public within EU Copyright Architecture', Common Market Law Review, 54(4), pp. 1221-1242.

Rosenmeier, M., SzKaleJ, K., Wolk, S. (2019) EU Copyright Law: Subsistence, Exploitation and Protection of Rights. Alphen aan den Rijn: Kluwer.

SEZGIN, E. (2018) 'Introduction to Current and Emerging mHealth Technologies: Adoption, Implementation, and Use' in Sezgin, E., Yildirim, S., Yildirim, S., Özkan-Yildirim, S., Sumuer, E. (eds.) Current and Emerging mHealth. Technologies Adoption, Implementation, and Use. Cham: Springer, pp. 1-6.

Silver, O. 'European Cyber Crime Proposal Released', Computer Fraud and Security, 2001/5, pp. 3-17.

SinRoD, J., REILlY, W., (2000) 'Cyber-Crimes: A Practical Approach to the Application of Federal Computer Crime Laws', Santa Clara Computer and High Technology Law Journal, 16(2): 1-53. 
Stownik Języka Polskiego [Online]. Available at: https://sjp.pwn.pl/sjp/cenzura;2447537.html (Accessed 15 May 2021).

SPEER, L. 'Redefining Borders: The Challenges of Cybercrime', Crime, Law and Social Change, 2000/34, pp. 259-273.

Strogowicz, M. (1959) Prawda obiektywna i dowody sq̨dowe w radzieckim procesie karnym. Warszawa: Wydawnictwo Prawnicze.

TERRY, N. (2000) 'Structural and Legal Implications of E-health', Journal of Health Law, 33(4), pp. 605-614.

VISSER, D. 'Hof van Justitie van de Europese Unie, 7 augustus 2018, C-161/17, ECLI: EU: C: 2018: 634', AMI: tijdschrift voor auteurs-, media-en informatierecht, 2018/8, 183-190.

VISSER, D. 'Kroniek van de intellectuele eigendom', Nederlands Juristenblad, 2018/93, pp. 1025-1037.

WALDEN, I. (2004) 'Harmonising Computer Crime Laws in Europe', European Journal of Crime, Criminal Law and Criminal Justice, 12(4), pp. 321-336.

WALtoś, S. (2014) 'Zasada prawdy materialnej' in Wiliński P. (ed.) System Prawa Karnego Procesowego. Vol. 3, Zasady procesu Karnego. Warszawa: Wolters Kluwer, 273-281.

WANG, F. 'Current Developments - Europe', Intellectual Property Forum: Journal of the Intellectual and Industrial Property Society of Australia and New Zealand, 2018/113, pp. 86-91.

WANG, S. (2007) 'Measures of Retaining Digital Evidence to Prosecute Computer-based Cyber-crimes', Computer Standards and Interfaces, 29(2), pp. 216-223.

WANG, X., LOVE, P., KIM, M., WANG, W. (2014) 'Mutual Awareness in Collaborative Design: An Augmented Reality Integrated Telepresence System', Computers in Industry, 65(2), pp. 314-324.

WIELEC, M. (2017) Wartości - analiza z perspektywy osobliwości postępowania karnego. Lublin: Academicon.

WINICK, R. (1994) 'Searches and Seizures of Computers and Computer Data', Harvard Journal of Law \& Technology, 8(1), pp. 75-128.

ZAJADŁO, J. 'Teoretyczne i filozoficzno-prawne pojęcie prawdy' in Kremens, K., Skorupka J. (eds.) Pojęcie, miejsce i znaczenie prawdy $w$ procesie karnym. Wrocław: Oficyna Prawnicza, 2013), 20-32.

ZAWIDZKA-ŁOJEK, A. Grzeszczak, R. (2015) Prawo materialne Unii Europejskiej. Warszawa: Instytut Wydawniczy EuroPrawo.

\section{Legal sources}

Decree of 5 July 1946 establishing the Main Office for the Control of the Press, Publications, and Public Performances (Journal of Laws of 1946, No. 34, item 210).

Convention for the Protection of Human Rights and Fundamental Freedoms, 4 November 1950, as amended (Journal of Laws of 1993, No. 61, item 284).

Code of Administrative Procedure Act of 14 June 1960 (consolidated text: Journal of Laws of 2021, item 735).

Civil Code Act of 23 April 1964 (consolidated text: Journal of Laws of 2020, item 1740, as amended).

Code of Civil Procedure Act of 17 November 1964 (consolidated text: Journal of Laws of 2021, item 11). 
Act of 31 July 1981 on the remuneration of persons holding state managerial positions (Journal of Laws of 2020, item 1637).

Press Law Act of 26 January 1984 (consolidated text: Journal of Laws of 2018, item 1914).

Copyright and Related Rights Act of 4 February 1994 (consolidated text: Journal of Laws of 2020, item 288).

Constitution of the Republic of Poland of 2 April 1997 (Journal of Laws of 1997, No. 78, item 483).

Directive 2001/29/EC of the European Parliament and of the Council of 22 May 2001 on the harmonisation of certain aspects of copyright and related rights in the information society, OJ L 167, 22.6.2001, p. 10.

Electronic Services Act of 18 July 2002 (consolidated text: Journal of Laws of 2020, item 344).

Treaty of Accession between the Kingdom of Belgium, the Kingdom of Denmark, the Federal Republic of Germany, the Hellenic Republic, the Kingdom of Spain, the French Republic, Ireland, the Italian Republic, the Grand Duchy of Luxembourg, the Kingdom of the Netherlands, the Republic of Austria, the Portuguese Republic, the Republic of Finland, the Kingdom of Sweden, the United Kingdom of Great Britain and Northern Ireland (Member States of the European Union) and the Czech Republic, the Republic of Estonia, the Republic of Cyprus, the Republic of Latvia, the Republic of Lithuania, the Republic of Hungary, the Republic of Malta, the Republic of Poland, the Republic of Slovenia, the Slovak Republic, concerning the accession of the Czech Republic, the Republic of Estonia, the Republic of Cyprus, the Republic of Latvia, the Republic of Lithuania, the Republic of Hungary, the Republic of Malta, the Republic of Poland, the Republic of Slovenia and the Slovak Republic to the European Union, signed in Athens on 16 April 2003, OJ L 236, 23.9.2003 (Journal of Laws of 2004, No. 90, item 864).

Act of 1 April 2004 amending the Copyright and Related Rights Act (Journal of Laws of 2004, No. 91, item 869).

Telecommunications Law Act of 16 July 2004 (consolidated text: Journal of Laws of 2021, item 576).

Act of 17 February 2005 on the computerization of the activities of entities performing public tasks (consolidated text: Journal of Laws of 2021, item 670).

Treaty on European Union and the Treaty on the Functioning of the European Union, OJ C 326, 26.10.2012, p. 1.

Personal Data Protection Act of 10 May 2018 (Journal of Laws of 2019, item 1781).

\section{Case law}

Judgement of the Court of Justice of the European Union of 8 September 2016 in case C-160/15 GS Media BV v Sanoma Media Netherlands BV, Playboy Enterprises International Inc., Britt Geertruida Dekker (ECLI:EU:C:2016:644).

Judgement of the Court of Justice of the European Union of 26 April 2017 in case C-527/15 Stichting Brein v Jack Frederik Wullems, also trading under the name 'Filmspeler' (ECLI:EU:C:2017:300).

Judgement of the Court of Justice of the European Union of 14 June 2017 in case C-610/15 Stichting Brein v Ziggo BV and XS4ALL Internet BV (ECLI:EU:C: 2017:456).

Judgement of the Court of Justice of the European Union of 7 August 2018 in case C-161/17

Land Nordrhein-Westfalen v Dirk Renckhoff (ECLI:EU:C:2018:634). 
Judgement of the Court of Justice of the European Union of 9 March 2021 in case C-392/19 VG Bild-Kunst v Stiftung Preußischer Kulturbesitz (ECLI:EU:C:2021:181).

Decision of the Court of Appeal in Warsaw of 21 June 2016, case ref. IA Cz 723/16.

Judgement of the District Court in Olsztyn of 6 June 2017, case ref. VII K 5/16.

Judgement of the Court of Appeal in Szczecin of 24 November 2016, case ref. I ACa 1159/15. Judgement of the Supreme Court of 9 August 2019, case ref. II CSK 7/18.

Judgement of the Constitutional Court of 29 November 2017, case ref. P 9/15. Judgement of the Constitutional Court of 6 December 2016, case ref. SK 7/15. Judgement of the Constitutional Court of 10 February 2015, case ref. SK 50/13. Judgement of the Constitutional Court of 12 December 2011, case ref. P 1/11. Judgement of the Constitutional Court of 10 May 2005, case ref. SK 40/02. Judgement of the Constitutional Court of 7 July 2003, case ref. SK 38/01. Judgement of the Constitutional Court of 10 June 2003, case ref. SK 37/02. Judgement of the Constitutional Court of 12 December 2011, case ref. P 1/11. Judgement of the Court of Justice of the European Union of 17 October 2017 in case C-194/16 Bolagsupplysningen OÜ and Ingrid Ilsjan v Svensk Handel AB (ECLI:EU:C:2017:766).

Judgement of the Court of Justice of the European Union of 25 October 2011 in joined cases C-509/09 and C-161/10 eDate Advertising GmbH and others v X and Société MGN LIMITED (ECLI:EU:C:2011:685).

Judgement of the Constitutional Court of 12 May 2008, case ref. SK 43/05. Judgement of the Constitutional Court of 14 December 2011, case ref. SK 42/09. Judgement of the Constitutional Court of 20 February 2007, case ref. P 1/06. Judgement of the Constitutional Court of 26 May 2008, case ref. SK 25/07. Judgement of the Constitutional Court of 28 June 2000, case ref. K 34/99. Judgement of the Constitutional Court of 29 September 2008, case ref. SK 52/05. Judgement of the Constitutional Court of 30 October 2006, case ref. P 10/06. 